\title{
Archeologické výzkumy na Pohansku u Břeclavi z pohledu archivních materiálů. Archiv archeologie nebo archeologie archivu?
}

\author{
Archaeological excavations at Pohansko u Břeclavi \\ from the view of archival materials. \\ An archive of archaeology, or archaeology of an archive?
}

\author{
Marie Salvetová
}

\begin{abstract}
Abstrakt
$\checkmark$ rámci uzavření autorčina studia na Ústavu archivnictví a pomocných věd historických došlo k uspořádání písemností shromážděných na archeologické základně Pohansko, k jejich organizaci a částečné skartaci. Bylo přiděleno celkem 817 inventárních čísel, vytvořen fond o rozsahu 14,5bm. Z dochovaných písemností pak byly sebrány informace, které mapují archeologické výzkumy od roku 1958 po rok 1990. Předložený článek přináši dějiny výzkumu pouze na základě dochovaných písemností (tedy pouze z "jednoho zdroje").
\end{abstract}

\section{Klíčová slova}

archivní fond; archiválie; písemnosti; archeologický výzkum; dějiny výzkumu; Pohansko u Břeclavi

\begin{abstract}
Within completion of studies of the author in the Department of Auxiliary Historical Sciences and Archive Studies, the written documents accumulated in the archaeological research base at Pohansko were sorted, organized and partly discarded. A total of 817 inventory numbers were assigned, and a collection sized 14,5 bm was established. From the written documents preserved then information was extracted concerning the archaeological excavations from 1958 to 1990. The paper presented is dealing with the history of research based only on the documents preserved (that is only on "one source")
\end{abstract}

\section{Keywords}

archive collection; archival documents; written documents; archaeological excavation; history of research; Pohansko u Břeclavi 


\section{1. Úvod}

Tento příspěvek mapuje archeologické výzkumy na významné lokalitě Pohansko u Břeclavi poněkud z netradičního úhlu pohledu - z pohledu dochovaných písemností. Vychází z autorčiny diplomové práce na Ústavu archivnictví a pomocných věd historických Masarykovy univerzity v Brně, která byla úspěšně obhájena v roce 2012. Autorka využila faktu, že je nejen diplomantkou na zmíněném ústavu, ale také dlouholetou technickou pracovnicí na archeologickém výzkumu na Pohansku u Břeclavi. Výzkumy na Pohansku jsou v České republice do určité míry fenomén - na našem území je jen málo lokalit, kde by probíhal systematický archeologický výzkum soustavně tak dlouho, vedený jednou institucí a jen několika vedoucími odborníky. Co víc, tento výzkum má zázemí ve zděné archeologické stanici, kde je možné uchovávat (nejen) dokumenty jakkoli spojené s výzkumem.

Archeologické výzkumy na Pohansku byly zahájeny $\mathrm{v}$ roce 1958 a od tohoto okamžiku se archeologům podařilo shromáždit úctyhodné množství nejen archeologických nálezů, ale také písemných, dnes už můžeme říci archivních, materiálů. Vzhledem $\mathrm{k}$ tomu, že nálezy z lokality jsou často předmětem zadaných studentských prací nejen na Ústavu archeologie a muzeologie MU v Brně, nebylo by vhodné písemnosti předat do Archivu Masarykovy univerzity, ačkoli tato možnost byla také zvažována ${ }^{1}$ - usoudili jsme, že písemnosti je potřebné mít k nahlédnutí kdykoli bez omezení.

Mezi těmito materiály nejsou pouze rukopisy archeologických zpráv a článků (i když tvoří podstatnou součást), ale také pracovní smlouvy a dohody s brigádníky, záznamy o řadě majetko-právních jednání a v neposlední řadě také doklady o další (zejména pedagogické) činnosti dlouholetých pracovníků na Pohansku.

Praktickou součástí diplomové práce bylo uspořádání a vhodné uskladnění těchto písem- ností, aby nadále netrpěly světlem, vlhkem, prachem a také častou a zbytečnou manipulací. Byly proto srovnány, pokud možno z nich byly odstraněny kovové součásti (sponky a svorky, které rezaví a tím poškozují také papír) a hlavně byly uloženy do archivních krabic. ${ }^{2} \mathrm{~V}$ souladu s př́lohou č. 2 k vyhlášce č. 645/2004 Sb., kterou se provádějí některá ustanovení zákona o archivnictví a spisové službě a o změně některých zákonů, byl vytvořen inventární seznam. Vzhledem k specifickým potřebám zpracovávaných archiválií byla podoba inventárního seznamu vytvořena přímo pro potřeby „archivního fondu“ Břeclav-Pohansko. V současné době tento inventární seznam obsahuje 817 inventárních čísel, a vlastní rozsah fondu vyjádřený v běžných metrech je cca 14,50 bm.

\section{Pětiletky}

Materiály, týkající se tzv. pětiletek, tvoří jeden z hlavních pramenů informací o archeologickém výzkumu na lokalitě Pohansko u Břeclavi. Během pořádání dochovaného archivního fondu byly tyto materiály shromážděny do tří standardních archivních krabic (č. kr. 1-3). Jedná se zejména o zápisy předběžných jednání, plány pětiletek, průběžné zprávy, hodnocení, závěrečné zprávy, oponentské posudky, záznamy závěrečného oponentního řízení a další dokumenty spojené se státními pětiletými plány. Jde o oficiální dokumenty, které byly určeny nejvyšším veřejně-státním orgánům a vědeckým odborníkům. Najdeme zde informace o finančním zabezpečování výzkumu během let a podobné správní záležitosti.

Konkrétně se zde nachází:

- Desítiletí 1959-1968 (hlavní úkol „Pravěké dějiny ČSSR‘, dílčí úkol ,Nová koncepce slovanského období na území ČSSR‘)

- Celková zpráva 
- Oponentské řízení

- 3. pětiletí 1969-1973 (hlavní úkol: ,Slované a první státní útvary na území Československa'; dílčí úkol: ,Vznik a rozvoj velkomoravského státu')

- Závěrečná zpráva

- Zpráva pro Ročenku UJEP

- 5. pětiletka 1971-1975 (hlavní úkol: ,Slované a první státní útvary na území Československa‘, dílčí úkol ,Vznik a vývoj velkomoravského státu', část dílčího úkolu ,Břeclav-Pohansko, výzkum slovanského hradiště‘)

- Souhrnná zpráva o 14 sezónách výzkumu Břeclav-Pohansko (1972)

- Zpráva o výzkumu Břeclav-Pohansko v roce 1973

- Zpráva o výzkumu Břeclav-Pohansko za rok 1974

- Zpráva o výzkumu Břeclav-Pohansko za rok 1975

- Zpráva o plnění úkolu výzkumu 5. pětiletky 1971-1975

- Obhajoba dílčí etapy výzkumného úkolu státního plánu

- Vydání přehledu vědecko-výzkumných úkolů

- Zpráva o výsledcích dosažených při řešení hlavního úkolu VIII-3-2

— 6. pětiletka 1976-1980 (hlavní úkol ,Slované a první státní útvary na území Československa‘, dílčí úkol: ,Vznik a rozvoj Velké Moravy")

- Zpráva o výzkumu Břeclav-Pohansko za rok 1976

- Zpráva o vědeckovýzkumné činnosti katedry za rok 1977

- Zpráva o vědecko-výzkumné činnosti za rok 1978

- Zpráva o výzkumu státního plánu v roce 1980
- Závěrečná zpráva o plnění SE SPZV č. VIII$4-4 / 2-2$

- 7. pětiletka 1981-1985 (dílčí úkol: „BřeclavPohansko')

- Výzkum státního plánu VIII-07-10/04/05 $\mathrm{v}$ roce 1981

- Zpráva o výsledcích výzkumu v Břeclavi-Pohansku v r. 1982

- Zpráva o výsledcích výzkumu v Břeclavi-Pohansku v r. 1983

- Zpráva o výsledcích výzkumu v Břeclavi-Pohansku v r. 1984

- Oponentní řízení

- 8. pětiletka 1986-1990 (dílčí úkoly: ,Geneze a proces formování státnosti, národnosti a raně feudální společnosti na území ČSSR a ,Raně feudální společnost Velké Moravy na základě objevů z Břeclavi-Pohanska')

- Potvrzení o zajištění úkolu SPZV na 8. pětiletku

- Návrh opatření ke komplexnímu kulturněpolitickému využití archeologické lokality Břeclav-Pohansko v 8. pětiletce

- Zpráva o plnění dílčího úkolu v roce 1986

— Zpráva o plnění úkolu SPZV v roce 1987

- Průběžné oponentské řízení za léta 1986-1987

- Zpráva o plnění úkolu SPZV v roce 1988

- Zpráva o plnění úkolu SPZV v roce 1989

- Zpráva o plnění úkolu SPZV v roce 1990

- Závěrečná zpráva o plnění úkolu SPZV za léta 1986-1990

- 9. pětiletka 1991-1995 (úkol: „K ekonomicko-společenské problematice Velké Moravy (na základě objevo̊ v Břeclavi-Pohansku“)

Jelikož se jedná o úřední, a tedy nepříliš čtivé materiály, domníváme se, že pro základní přehled postačí souhrnná tabulka (viz Tab. 1). Bo- 
hužel ne ve všech letech jsou uvedeny všechny údaje, jelikož ne všechny dochované písemnosti potřebné údaje poskytují. Jak bylo výše sděleno, nejedná se o čtivé materiály, ale přesto přinášejí praktické informace.

Pojd’me se pro zajímavost blíže podívat poněkud extrémní roky na počátku výzkumu - logicky právě při zahájení dlouhodobých výzkumů byly provedeny největší investice, zejména stavba zděné archeologické základny. Výzkumné sezóny trvaly 8,9 měsíců za přítomnosti velkého množství dělníků. ${ }^{3}$ Např. v roce 1961 bylo od 1 . března do 1 . prosince prokopáno 167 čtverců $5 \times 5 \mathrm{~m}-4175 \mathrm{~m}^{2}$ (z toho 112 čtverců u kostela, v lesní školce 43 čtverců a 12 čtverců na žárovém pohřebišti). Z těchto ploch pak bylo zinventováno 13620 nálezů (!). Podobně rok na to, 1962, 29 dělníků během 6 měsíců prokopalo plochu 189 (!) čtverců $5 \times 5$ m a řez valem o rozměrech $19 \times 8 \mathrm{~m}$ - celkem tedy 4927 m2; zainventováno bylo „pouze“ 11637 nálezů. Pro srovnání: v roce 2015 bylo během 6 týdnů prokopáno 15 čtverců $5 \times 5 \mathrm{~m}$, tzn. $375 \mathrm{~m}^{2}$.

Na druhou stranu vyhraněný byl počátek 80 . let, který se alespoň podle dochovaných zdrojů nesl ve znamení velkých finančních problémů - v sezóně 1980 byl terénní výzkum téměř pozastaven z důvodu nedostatku financí na dělnické mzdy (pouze 18 000) - práce tak v tomto roce prováděl pouze 1 dělník po dobu 3 měsíců, 2 studenti (odpracovali celkem 4 týdny) a 2 neplacení dobrovolníci (odpracovali 3 týdny). Podobně v roce 1981 práce prováděl pouze jeden dělník a praktikující studenti.

V závěrečné zprávě o výsledcích výzkumu v Břeclavi-Pohansku v r. 1983 jsou také zmíněny velké obtíže s řešením finančních problémů, k jejichž vyřešení došlo po dlouhé nejistotě a intenzivním jednání „při značném nervovém vypětí" až na konci kalendářního roku. Vedoucí výzkumu si posteskl, že „opět došlo k chronickému nedostatku, tj. opožděnému proplácení mezd dělníků, což nepřispělo k zvýšení pracovní morálky.“

Komplikovanou finanční situaci mělo zřejmě pomoci řešit zařazení archeologických výzkumů na Pohansko do LAS (Letní aktivity studentů), které se podařilo v roce 1983. Na základě dochovaných listů mezi představiteli výzkumu a tajemníkem ústředního výboru Socialistického svazu mládeže, ředitelem odboru vědy ministerstva školství a tajemníkem KV SSM Brno bylo plánováno zařazení (a spolufinancování) archeologického výzkumu Břeclav-Pohansko do akcí letní pracovní aktivity studentů. Podle těchto dochovaných listů se mělo jednat o 20 studentů po dobu 2,5 měsíce každý rok. Jak ale ústně sdělili pamětníci, další roky Pohansko už do LAS zařazeno nebylo.

Určitou zajímavost představuje existence tzv. 9. pětiletky (1991-1995). Je jistě pozoruhodné, že systém pětiletého plánování přetrval i přes politické otřesy, které náš stát v této době zažíval. Úkol poslední pětiletky byl K ekonomicko-společenské problematice Velké Moravy (na základě objevů v Břeclavi-Pohansku).

\section{Komise pro Pohansko}

Na základě archivních materiálů bylo zjištěno, že v Břeclavi vznikla Komise pro Pohansko, která se scházela (alespoň zpočátku) každý měsíc, aby řešila aktuální problémy spojené s touto lokalitou. Pravidelnými účastníky byli zástupce ONV, MěNV Břeclav, katedry prehistorie UJEP Brno, Lesního závodu Břeclav, muzea Břeclav atd.

V archivním fondu Břeclav-Pohansko jsou dochovány zápisy ze schůzí konaných od dubna 1960 do září 1962. Nejsou zde zřejmě zachovány zápisy ze všech schůzí, zejména rok 1961 je zastoupen velmi fragmentárně.

Několik zápisů ze zasedání Komise pro Pohansko se nachází také v AMU. Jedná se o schů- 


\begin{tabular}{|c|c|c|c|c|c|c|c|c|}
\hline Rok & $\begin{array}{c}\text { mzdy } \\
\text { dělníků }\end{array}$ & $\begin{array}{c}\text { DKP a } \\
\text { materiál }\end{array}$ & $\begin{array}{c}\text { foto- } \\
\text { materiál }\end{array}$ & $\begin{array}{l}\text { kreslící } \\
\text { potřeby }\end{array}$ & služby & telefon & $\begin{array}{c}\text { výzkumná } \\
\text { sezona }\end{array}$ & $\begin{array}{c}\text { průměrný } \\
\text { počet } \\
\text { dělníků }\end{array}$ \\
\hline 1959 & 45000 & 8231,67 & 1114,7 & - & 452,55 & & 4. 5. - 9. 10. & 11,5 \\
\hline 1960 & 228749 & 39649,99 & 8377,78 & 285,7 & 8623,07 & & 5. 3. - 30. 10. & $33 *$ \\
\hline 1961 & 181760 & 41648,62 & 9921,46 & 1396,6 & 20575,17 & 580,4 & 1. 3. - 1. 12. & $25^{*}$ \\
\hline 1962 & 177149 & 25726,89 & 6244,2 & 1021,25 & 10821,03 & 1620,44 & 2. 4. - 1.10. & 29 \\
\hline 1963 & 160000 & 16421,23 & 8642,28 & 500 & 11518,34 & 1913,4 & 20. 4. - 31. 10 & 27 \\
\hline 1964 & 100608 & 8007,17 & 6541,26 & 2360,9 & 6606,35 & 494,7 & 15. 4. - 15. 10. & 18 \\
\hline 1965 & 95534 & 5396,99 & 8796,55 & - & 12945,6 & 681,4 & 24. 5. - 3. 11 & 19 \\
\hline 1966 & 62783 & 3565,59 & 8398,65 & 351 & 8207,96 & 1496,02 & 14. 5. - 30. 9. & 11 \\
\hline 1967 & 53287 & 6006,5 & 3616,45 & 2117,5 & 2513,31 & 868,1 & 15. 5. - 31. 10. & 11 \\
\hline 1968 & 37802 & 4527,33 & 3142,02 & 472 & 22652,64 & 970,8 & 1. 4. - 27.9. & 10 \\
\hline 1969 & 48802 & 12181,91 & 10276,05 & 3711 & 19958,7 & 853,3 & 4. 5. - 30. 9. & 11 \\
\hline 1970 & 60783 & 20491,75 & 2500 & 2500 & 4934,4 & 1573,8 & 24. 4. - 30.9. & 22 \\
\hline 1971 & 34575 & 3127,05 & 2500 & 2500 & 21713,5 & 2334,6 & $26.4 .-30.9$. & 7 \\
\hline 1972 & 87200 & 31771,09 & 2500 & 1000 & 21280,6 & 4039 & 10. 4. - 30. 10. & 11 \\
\hline 1973 & 52360 & 26834 & & & 31606 & & & \\
\hline 1974 & 97871 & & & & & & & \\
\hline 1975 & 88709 & 12689,4 & & & 12076,6 & & & \\
\hline 1976 & 129762 & 27161 & & & 66552 & & & \\
\hline 1977 & 123539 & 23834 & & & 11509 & & & \\
\hline 1978 & 199687 & 25511 & & & 27376 & & & \\
\hline 1979 & 178254 & 31289 & & & 7638 & & & \\
\hline 1980 & 85390 & 11439 & & & 1299 & & & 1 \\
\hline 1981 & 25750 & 797,5 & 2208,9 & & 22786 & & 15. 6. - 31. 8 & 1 \\
\hline 1982 & 44425 & 8770,2 & & & 3736 & & & \\
\hline 1983 & 60689 & 3014 & & & 10604 & & & \\
\hline
\end{tabular}

Tab. 1. Přehled výzkumných sezón na Pohansku na základě oficiálních úředních dokumentů

Tab. 1. An overview of excavation campaigns at Pohansko according to official documents

ze konané 2. dubna 1963, 9. července 1963, 13. února 1964, 2. dubna 1964, 20. dubna 1964 a 8. ř́jna 1964 (AMU, fond A2, sig. CI/2, k. 2). Toto dokazuje, že Komise fungovala ještě v roce 1964, ačkoli v archivním fondu na Pohansku už tomu nic nenasvědčuje.

\section{Dějiny výzkumu na základě dochovaných písemností ${ }^{4}$}

Sondážní průzkum rozsáhlého hradiska Pohansko byl v roce 1958 proveden Prehistorickým ústavem brněnské univerzity $\mathrm{v}$ rámci rezortního výzkumného úkolu HA 55 - komplexní archeologicko-historický výzkum Znojemska a Podyjí. 
Podle deníku prací (inv. č. BP 403) se první průzkum uskutečnil 2.-6. zářrí. ${ }^{5}$

Před zahájením vlastních sondážních výkopů bylo celé hradisko popsáno, a podle záznamů v deníku byly z důvodu zjištění půdních podmínek před zahájením vlastního systematického výzkumu položeny 3 větší a několik malých sond „které byly provedeny tak, aby nemohly porušit nálezovou situaci, která bude zjištována systematickým výzkumem."

Během prvotního průzkumu hradiska se podařilo archeologům také sebrat cenné informace od pamětníků, týkající se Pohanska - byli např. upozorněni na jezevčí noru „ve východní straně valu, 98 kroků SV od bodu, v němž lesní cesta vedoucí k zámečku protíná val...".

Vlastní výkop systematického archeologického výzkumu na Pohansku byl zahájen za přítomnosti B. Dostála 6. května 1959. 7. května 1959 si „mezi 15:15-16:30 prohlédl výzkum prof. Kalousek, který přijel rektorátním autem.“ (Kronika 1959, 3). Podle seznamu v kronice výzkumu pracovali při výzkumu tito dělníci: ${ }^{6}$

- Barančič Josef, Břeclav (*1892)

- Boráň Jan, Břeclav (*1885)

- Butová Anna, Poštorná (*1930)

- Hladůvka František, Poštorná (*1895)

- Nesvadba Richard, Břeclav (*1897)

- Pavelka Antonín, Břeclav (*1886)

— Stepaniuk Lew, Břeclav (*1888)

K pracovníkům v létě přibyli ještě i posluchači (Tejral, Klanica atd.), postupně byli přijati další dělníci. Během sezóny byla prozkoumána asi 1/250 opevněné plochy hradiska. Pracovalo se za těžkých podmínek, pracovníci byli nuceni se převlékat ve volné př́rodě bez možnosti používat nejzákladnějších sociálních zařízení.“ (Investiční záměr 1960, 4).

Dne 24. července 1959 se na Pohansku konala první odborná komise, která se jednomyslně shodla na závažnosti nalezené budovy s orientací k severovýchodu, s poměrně mělkým uložením základů.

Výnosem MŠK ze dne 10. září 1959 byl výzkum na Pohansku zařazen mezi stěžejní vědecko-výzkumné práce v oboru archeologie. Tento výzkum byl také pojat do 3. pětiletky a stal se základem veškeré pedagogické, vědeckovýzkumné a veřejně-politické činnosti katedry prehistorie.

$\mathrm{Na}$ základě dochovaných písemností se dozvídáme, že v roce 1960 výzkum trval osm měsíců a na manuální práci se podílelo v letních měsících až na 50 pracovníků. Práce se zaměřily na chrámovou stavbu a její okolí, kamenné destrukce jižně chrámu, proběhl také záchranný výzkum v prostoru SV předhradí v místech stavby archeologické stanice a zjištovací výzkum na JZ předhradí.

Roku 1960 byla na tzv. Severovýchodním předhradí po předchozím archeologickém průzkumu (více Deník výzkumu Severovýchodního předhradí) a po získání všech potřebných povolenî postavena zděná archeologická základna. S obestavěným prostorem 1236,25 m3 tvořila asi 1/3 základny archeologické lokality v Mikulčicích. V březnu 1960 byla také naplánována stavba pavilonu č. 2, a to na rok 1963. Jak dnes víme, ke stavbě druhé stanice doposud nedošlo. Optimismus dokazuje také plánování zastřešení 3 odkrytých kostelů v letech 1961, 1963 a 1965 po 90 tisících Kčs.

Rozsáhlá nálezová zpráva o výzkumu 407 hrobů u kostela na hradisku patří do roku 1961. V tomto roce bylo položeno 15 zjištovacích sond v prostoru lesní školky a v létě stejného roku podniknut plošný odkryv 40 čtverců $5 \times 5 \mathrm{~m}$. Také byly v jihozápadní části opevněného areálu položeny sondy, které zjistily žárové pohřebiště s keramikou pražského typu. ${ }^{8} \mathrm{~K} 1.1$ 1. 1961 byl ustanoven správce výzkumné stanice na Pohansku, prvním se stal Richard Nesvadba z Břeclavi.

$\mathrm{V}$ roce 1961 byl proveden ověřovací plošný odkryv na vnější (jižní) straně valu a napřičc va- 


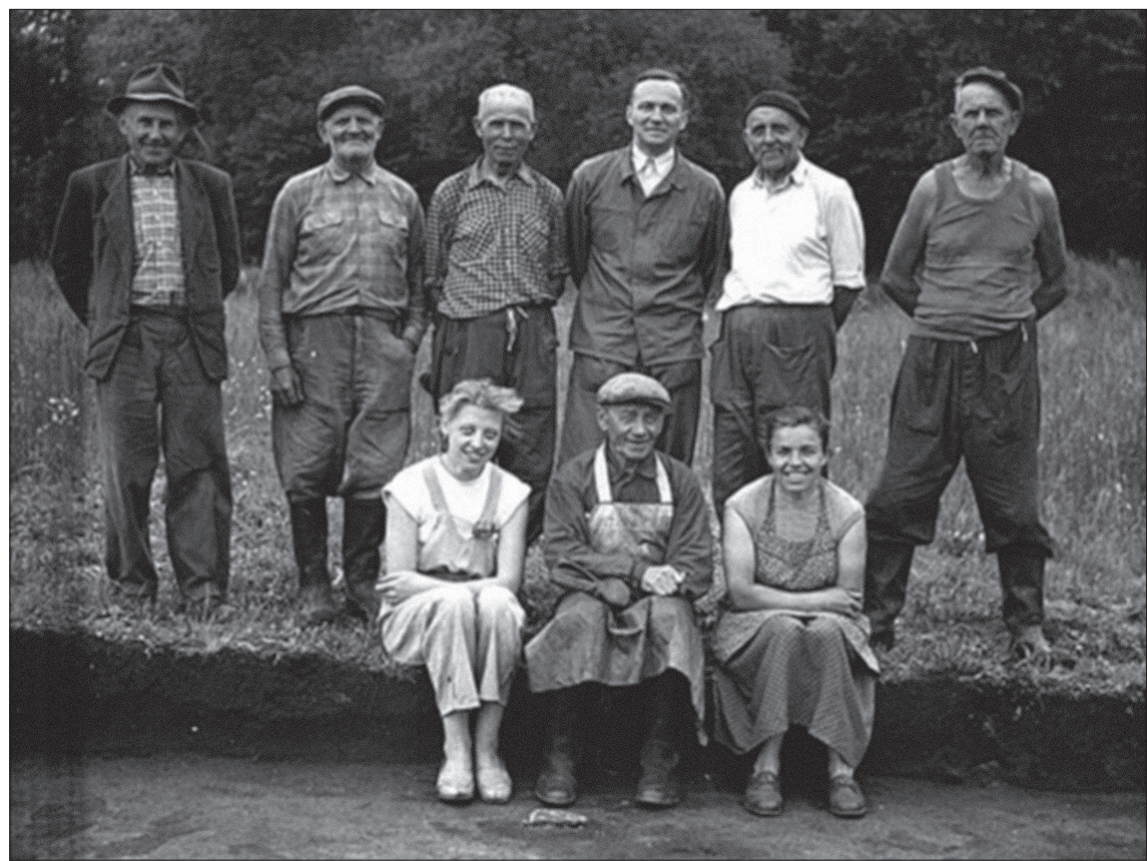

Obr. 1. První pracovní tým na Pohansku (archiv ÚAM).

Fig. 1. The first work team at Pohansko (Archive of the Department of Archaeology and Museology).

lem vedena druhá sonda. $\mathrm{V}$ těchto místech byl pak v r. 1962 proveden systematický výzkum. Ve stejném roce, po odsouhlasené hluboké orbě v místě vyžilého prutníku, na ploše 3,98 ha v prostoru rozsáhlého předhradíjižně od opevněného hradiska Pohansko, byly průzkumem objeveny rozrušené sídlištní objekty z 9.-10. století a také hroby. Vzhledem k tomu, že výsadba nových dřevin by znemožnila archeologický výzkum a navíc zcela zničila už tak porušené objekty, bylo rozhodnuto o zastavení prací.

$\mathrm{V}$ roce 1963 se pokračovalo ve výzkumu sondy valem z předchozí sezóny, výzkum byl proveden až na podloží - na úroveň výzkumu předešlého roku (přibližně $25 \mathrm{~cm}$ pod velkomoravský horizont).

Ve dnech 7.-9. července 1965 byl v široké části valu před lesní školkou vytyčen 5 metrů široký úsek tzv. Valu III. Výnosem ministerstva školství a kultury ze dne 30. listopadu 1965 byla zrrízena archeologická památková rezervace „Břeclav-Pohansko“ (číslo rejstříku ÚSKP: 22702/7-1169), ${ }^{9}$ která zaujímá plochu přibližně 93 ha.

$\mathrm{V}$ následujícím roce byly vyměřeny a prozkoumány Valy XI a XII, ke kterým se dochovala nálezová zpráva inv. č. BP 042. V únoru 1969 objednal vedoucí katedry František Kalousek panelovou garáž typu Prefa, o rozměrech $334 \times 545 \mathrm{~cm}$. Objekt musel být postavený na předem vybetonované základy. ${ }^{10} \mathrm{~V}$ této době se pracovníci tehdejšího Ústavu archeologie a muzeologie také snažili o stavbu trubkové fotověže, bohužel marně. ${ }^{11}$

$\mathrm{V}$ roce 1971 se archeologové pokoušeli o vyjmutí areálu ze zemědělské plochy. $\mathrm{V}$ podkladech je zdůrazněno, že ačkoli Pohansko bylo vyhlášeno archeologickou památkovou rezervací, přesto stále dochází na zemědělských pozemcích k poškozování ze strany Lesního 
závodu Břeclav, který platí z pozemků zemědělskou daň, a proto se je tedy snaží využívat. Vzhledem k tomu jsou orbou poškozovány dosud neprozkoumané objekty. S přihlédnutím k výše uvedenému bylo považováno za nutné vyjmout louky v areálu rezervace $\mathrm{z}$ fondu zemědělské půdy, a aby byly ponechány jako bezvýnosný pozemek.

Výstavba dřevěných chatek INOVEC k provizornímu ubytování sezónních pracovníků a studentů při archeologickém výzkumu byla povolena 21. dubna 1972. Podle kroniky výzkumů 1973 probíhal výzkum na žárovém pohřebišti, v roce 1974 pak v Lesní školce. V roce 1974 rozeslal vedoucí katedry R. M. Pernička několik žádostí o zvýšení finanční částky na mzdy dělníků na archeologickém výzkumu. V roce 1974 byla Pohansku přidělena kvóta 40.000,- Kčs, která zdaleka nedostačovala na pokrytí nákladů archeologického výzkumu. Vedoucí katedry upozornil, že aby byla archeologická stanice rentabilní, je vhodné, aby terénní práce provádělo 10-12 dělníků po dobu asi 4 měsíců. Dělníci pracující na Pohansku navíc žádali zvýšení hodinové mzdy na úroveň obvyklou na jiných pracovištích.

Na podzim 1974 se začala plánovat rekonstrukce stávající archeologické stanice na Pohansku. Bylo plánováno, že stávající objekt archeologické stanice bude na jaře 1975 rekonstruován a rozšíŕen o přístavbu o rozměrech cca $12 \times 20 \mathrm{~m}$. Podle předběžného záměru měly být v nové přístavbě umístěny pokoje pro brigádníky a hosty, sociální zařízení, skladiště, kuchyně a jídelna. Jednání úspěšně pokračovala včetně bezproblémové korespondence s tajemníkem fakulty ohledně zakoupení stavebního materiálu a sepsáním návrhu dohody o vypracování projektu na generální opravu. Jisté však je, že $\mathrm{k}$ přístavbě nedošlo. Z dochovaných archivních materiálů není možné určit, proč nakonec k naplánované rekonstrukci nedošlo. Podle ústního sdělení současného správce budovy, Pavla
Čápa, který na Pohansko nastoupil v březnu 1975, došlo k odebrání přislíbených finančních zdrojů, a proto nemohla být př́stavba realizována, i když už v jejím místě proběhl archeologický záchranný výzkum. Oznámení o nedostatku financí zřejmě proběhlo telefonickou formou, v př́islušné složce se nedochoval žádný dokument o tomto rozhodnutí.

Dnem 1. ledna 1974 byl empírový lovecký zámeček Pohansko a správa archeologické rezervace převeden do majetku a správy Krajského střediska státní památkové péče a ochrany př́rody. Pracovně náročný byl rok 1975 - v tomto roce proběhl výzkum v Lesní školce, Valu XIV, Severovýchodního předhradí a záchranný výzkum na Jihozápadním předhradí (v rámci stavební akce „Soutok Moravy a Dyje“). Dle fotodeníku bylo vyfoceno 93 fotografických filmů po 12 snímcích. V podstatě na stejných polohách se pokračovalo s pracemi i v roce 1976 . V následujícím roce (1977) probíhal záchranný výzkum na Jihozápadním předhradí a systematický výzkum na Severovýchodním předhradí. V květnu 1977 vypracoval vedoucí výzkumu Bořivoj Dostál Instrukci, v níž shrnul základní pravidla pro polní a kabinetní fotografickou dokumentaci archeologického výzkumu v Břeclavi-Pohansku.

Díky dochovanému výpisu k 1. prosinci 1977 víme, že celková hodnota staveb a inventáře činila 771 227,- Kč. Bylo by zajímavé srovnat dnešní hodnotu staveb a inventáře, bohužel se je nepodařilo zjistit. Na dotaz adresovaný ekonomickému oddělní FF přišla odpověd', ve které bylo poukázáno na nutnost „poradit se s nadřízeným a právníky“. ${ }^{12}$

Sezóna 1978 byla pro archeologický výzkum na Pohansku jubilejní dvacátá. S tímto vědomím probíhala během roku řada akcí, včetně přednášek a výstav. Vše vyvrcholilo uspořádáním mezinárodního sympozia „Slované 6.-10. století“, které se konalo v Břeclavi ve dnech 18.-21. záŕí 1978. Ze sympozia v roce 1980 Bořivoj Dostál a Jana Vignatiová sestavi- 


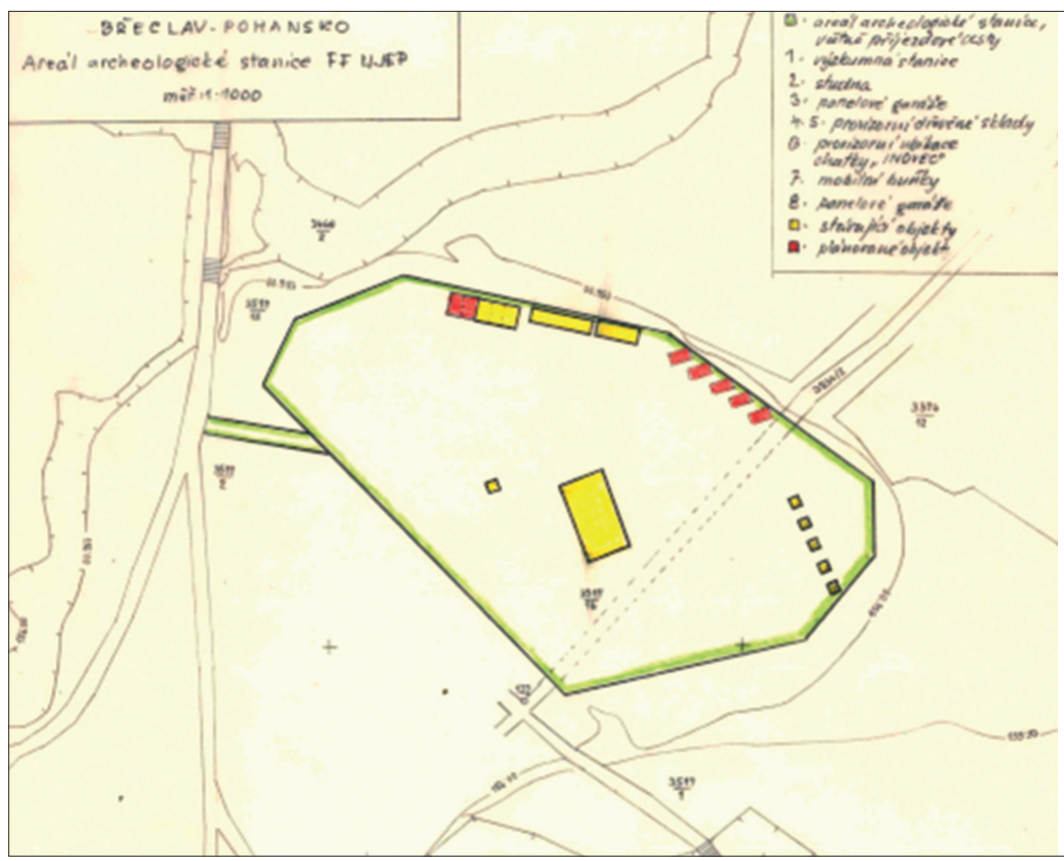

Obr. 2. Areál archeologické stanice (zeleně) s vyznačenými stávajícími objekty (žlutě) a nově přistavenými objekty (červeně) (inv. č. BP 483).

Fig. 2. The area of archaeological research base (green) with marked existing facilities (yellow) and newly built facilities (red) (Inv. No. BP 483).

li sborník referátů s názvem Slované 6. - 10. století. Sborník referátů ze sympozia BřeclavPohansko $1978 .{ }^{13} \mathrm{~V}$ tomto roce probíhal kromě systematického výzkumu zařazeného do státního plánu ještě také záchranný výzkum JZ předhradí. Dnem 1. 1. 1978 převzala katedra archeologie a muzeologie osobní vozidlo Škoda 1202 STW. Vozidlo bylo určeno výhradně pro potřeby výzkumného archeologického pracoviště na Pohansku, s tím, že s ním budou prováděny pouze jízdy na trase Pohansko - Břeclav a okolí. ${ }^{14}$

V dubnu 1978 udělil odbor výstavby Městského Národního výboru v Břeclavi souhlas s dočasným umístěním 5 mobilních buněk a 2 garáží v areálu archeologické stanice (viz Obr. 2).

Kompletně na výzkumy $\mathrm{z}$ předchozích let navázaly archeologické výzkumy v roce 1979 jak v Lesní školce, tak na JZ předhradí. Během těchto výzkumů bylo vyfoceno 348 fotografií (29 filmů po 12 snímcích), odborná komise se na Pohansku sešla 16. října 1979. Josef Poulík (z pozice koordinátora úkolu státního plánu VIII4-4/2-2 - Výzkum slovanského osídlení Břeclavi-Pohanska v 6.-10. století) zaslal dne 14. srpna 1979 list ministru školství ČSR Milanu Vondruškovi. Účelem dopisu byla žádost, aby ministerstvo školství dále poskytovalo UJEP zvýšenou dotaci pro výzkum slovanského osídlení Pohanska v dosavadním rozsahu 120000 Kčs ročně - od roku 1980 totiž „nebude již možno při záchranných pracích v plné míře využít případného finančního příspěvku investora vodohospodářských úprav, nebot nové směrnice MŠ ČSR o vedlejší hospodářské činnosti na VŠ výrazně omezují jeho použití při archeologických výzkumech.“

Podle očekávání se v roce 1980 projevil nedostatek financí - výzkumy byly zahájeny 2 . června 
s 1 dělníkem (J. Pyskatý), v červenci a v srpnu pracovali na výzkumu také studenti, do deníku nálezů bylo zaznamenáno 55 nálezů - včetně skupin nálezů, např. střepy; fakticky bylo tedy nálezů víc. V roce 1980 byly konečně pořízeny dvě garáže, které byly povoleny už v roce 1978 (viz výše, Obr. 2).

Podobně skromný byl i výzkum v roce 1981, ve kterém probíhal výzkum v Lesní školce s 94 zainventovanými sáčky a U Východní brány (kdy bylo zainventováno celkem 33 sáčků). Úsek pro výzkum byl zvolen v místě, kde se ve valu projevovala výrazná proláklina. Vzhledem k nízkému stavu dělníků (z důvodu nedostatku financí na mzdy) se vedoucí výzkumu rozhodl nekopat přímo prostor předpokládané brány ve valu, ale její předpolí na vnitřní straně hradiska. Ruční skrývka jednoho dělníka byla neefektivní, byl proto objednán buldozer, který odstranil část svrchní vrstvy.

Vlastní řez valem v prostoru Východní brány (tzv. Val XVI) byl proveden až v roce 1982 , i když i tento rok byl finančně omezen a na výzkumu pracovali 2 dělníci. Odborná komise se konala 26. ř́ijna 1982 a účastníci komise si prohlédli oba zkoumané úseky - část sídliště v Lesní školce a zmíněný řez valem ve východní části hradiska.

V roce 1983 byl výzkum v Břeclavi-Pohansku zařazen do akce Letní studentské aktivity, tato událost pomohla částečně řešit tíživou finanční situaci z minulých let. ${ }^{15}$ Archeologický výzkum prováděli především studenti filozofické fakulty UJEP v Brně. Výzkum navázal na výkopové práce z let 1981 a 1982 v prostoru východní brány. Práce se soustředily na 3 úseky - pokračování řezu valem č. XVI; řez valem XVII/83 severně od řezu XVI, kterým byl dokončen výzkum brány; a bylo otevřeno 8 a půl čtverce u východní brány, v sektoru D.

Dne 3. listopadu 1983 proběhlo jednání o kulturně-politickém a vědeckém využití archeo- logického výzkumu na Pohansku, po diskuzi se účastníci ${ }^{16}$ shodli na těchto závěrech:

- Vzhledem k blížícímu se výročí úmrtí sv. Metoděje v roce 1985 je nutné počítat se zvýšeným zájmem o velkomoravské památky - upravit lokality do stavu vhodného k reprezentaci, čelit „nesprávným tendencím“.

- Zajistit finanční dotaci v dostatečném časovém předstihu pro zajištění plynulého průběhu výzkumu - přiměřená výše 100 tisíc Kčs.

- Do 5 let uvést lokalitu do takového stavu, aby „důstojně reprezentovala jak vysokou úroveň čs. archeologie, tak péči státu o kulturní památky“. K tomu KNV zabezpečí 1 mil. Kčs na rekonstrukci.

- K zjednodušení navštěvování lokality upřesnit pravidla s PS, stálou údržbu přístupové cesty a jejího okolí, propagaci apod.

- Pro zvýšení publicity výzkumu v souvislosti s rokem 1985 vydat vícejazyčné průvodce.

Bohužel roku 1984 bylo opět vše při starém, minimálně co se financování týká. Pohansko nebylo zařazeno do LAS a objevila se nejistota ohledně finančních prostředků. ${ }^{17} 14$. října je datována písemná žádost o finanční zajištění výzkumu Pohanska, ve které vedoucí výzkumu B. Dostál urguje, že aby bylo možné „udržet výzkum na náležité úrovni, splnit úkoly SPZV a přiblížit se částce, která byla na tuto pětiletku řádně plánována“ bylo by potřeba alespoň 50 tisíc. Zároveň aby byla pro další léta stabilizována každoroční částka cca 75-100 tisíc Kčs. ${ }^{18}$ „Tuto částku bychom měli znát včas, tak abychom mohli...provést nábor pracovníků v průběhu přednáškového období, a aby bylo možné vyřídit s předstihem propustky do hraničního pásma (v němž Pohansko leží), jejichž vyřizování trvá vzhledem k prověřování kádrových fakt bezpečnostními orgány 1-2 měsíce.“. K zamyšlení je potom fakt, že velmi podobné listy - až na drobnosti prakticky totožné, včet- 
ně výše citované doušky o nutnosti znát částku včas - jsou datovány 5 . března 1985,5 . března 1986, 14. ledna 1987 a 2. února 1988.

Podle odborné komise, konané na Pohansku 13. září, výzkum v sezóně 1984 potvrdil malý výskyt obytných objektů v lesní školce a dovolil uvažovat o zaměření tohoto areálu na řemeslnou výrobu.

Logickým pokračováním archeologického výzkumu z předchozího roku je sezóna 1985, prázdninové práce na výzkumu prováděli studenti ze Střední průmyslové školy chemické v Ostravě a studenti FF UJEP. V roce 1985 bylo potřeba prodloužit Hospodářskou smlouvu o dočasném užívání. Sama hospodářská smlouva byla uzavřena 18. května 1977 a týkala se užívání parcely č. 3517/16, na které se rozkládá areál archeologické stanice. V roce 1985 Lesní závod Jihomoravských státních lesů v Židlochovicích tuto parcelu začlenil do nově vzniklé parcely č. $3517 / 1$ o výměře 2,2838 ha (původní parcela $3517 / 16$ byla o výměře 0,8768 ha). ${ }^{19}$

Další zkoumaná plocha navazovala na jižní stranu výzkumu z let 1985 a 1984, ${ }^{20}$ výzkum byl zahájen 1. července $1986 \mathrm{~s}$ asi 20 studenty z chemické průmyslovky, z FF UJEP v Brně a z gymnázia v Břeclavi. Z let 1986-1990 jsou mezi písemnostmi dochovány také zprávy o služebních cestách, které zaměstnanci (zejména B. Dostál) vykonávali - nejčastěji pochopitelně právě z Brna na Pohansko, ale také do Uherského Hradiště, Prahy, Strážnice atd.

Dne 29. června 1987 byly započaty výzkumné práce nové sezóny, hlavní pracovní sílu tvořili v červenci 1987 studenti ekonomické průmyslovky z Ostravy a studenti (popř. absolventi) historických oborů FF UJEP. Na konci července a v srpnu prováděli na výzkumu praxi posluchači 2. ročníku oboru archeologie z Brna; odborná komise se na Pohansku sešla 20. srpna 1987.

Výzkumy v roce 1988 navázaly na zkoumanou plochu z předchozího roku, společně pak vytvořily podobu obráceného písmene L.
Vlastní výzkumné práce začaly 4. července, do 1. srpna probíhala ruční skrývka zeminy, 2. srpna začalo vybírání objektů. Na výzkumu kromě studentů archeologie pracovali také studenti stavební průmyslovky z Brna (Kudelova 8), vysokoškolští studenti z Prahy (z lékařské fakulty, VŠE, FAMU), z Ostravy (absolventi SPŠCH) a gymnazisté z Litvínova.

Výzkum v Lesní školce roku 1989 probíhal v návaznosti na plochy z let 1985, 1987 a 1988. kopáčské práce v terénu prováděli studenti průmyslové školy stavební z Brna, studenti z gymnázia v Břeclavi, studenti různých oborů filozofické fakulty UJEP v Brně a vysokoškolští studenti z Prahy. ${ }^{21}$ Seznam brigádníků na Pohansku v době 1. července - 31. srpna 1989 čítá 56 jmen. Podle uzavřených dohod o pracovní činnosti většina brigádníků pobírala 8,50 Kčs za hodinu a jejich pracovní týden měl 42,5 hodiny. Stejného roku byl zakoupen polský detektor kovů pro archeologické výzkumy, za 13836 ,- Kčs, ${ }^{22}$ plus byla ještě později dokoupena anténa a pomocné sluchátko za 4 491,- Kčs.

Také v sezóně 1990 se výzkum konal v areálu Lesní školky u valu, v návaznosti na úseky zkoumané v letech 1988 a 1989. Na výzkumu kromě českých středoškolských a vysokoškolských studentů též 14 dní pracovali posluchači archeologie z univerzity v Göteborgu, Švédsko. Politický převrat v listopadu 1989 přinesl uvolnění dřive př́ísně střeženého pohraničního pásma. ${ }^{23}$ Druhou stranou mince byla nejistá pozice vysokého školství v nově obnoveném demokratickém státu a zejména nejisté financování. Proto také výzkumná sezóna 1990 byla tímto poznamenaná.

\section{Další materiály uložené na Pohansku}

Kromě písemností, které se týkají prrímo archeologických výzkumů na Pohansku u Břeclavi, se 
na Pohansku nachází také několik, které nejsou přímo vázány na lokalitu a archeologické výzkumy zde prováděné. Jedná se o Kroniku Prehistorického ústavu, dále dokumenty spojené s další odbornou praxí pracovníků a vedoucích výzkumu, jako jsou odborné články, separáty, zápisy z odborných komisí na jiných lokalitách apod., také novoročenky a část korespondence $\mathrm{z}$ pozůstalosti bývalého vedoucího a po mnoho let zástupce vedoucího na Pohansku, Bořivoje Dostála.

Mezi materiály najdeme též doklady prezentace archeologického výzkumu - at̉ už v rámci muzea v empírovém loveckém zámečku Pohansko, nebo odrazy výzkumů v dobových médiích - součástí archivního fondu na Pohansku je také jedna krabice novin a novinových výstřižků. O poznání horší je situace v případě televize přímo v archivním fondu se nedochovaly žádné audiovizuální záznamy a pouze několik písemných zmínek v kronikách o návštěvě reportérů, popř. fotografií z natáčení. Bohužel podobná je situace i v případě audio nahrávky, a ani oslovení Českého rozhlasu nepřineslo plody - žádná z (v kronikách přesně jménem i datem označených ${ }^{24}$ ) reportáží bohužel nebyla v archivu Československého rozhlasu archivována. Během let, kdy probíhá archeologický výzkum velkomoravského hradiska Pohansko, pronesli odborníci řadu přednášek - at̉ už odborných, ale zejména těch popularizačních. Tak jako v př́ípadě rozhlasových relací, také o přednáškách máme jen málo dochovaných informací.

\section{Závěr}

Dochované písemné dokumenty nám umožnily nahlédnout na systematický archeologický výzkum z jiné perspektivy a také různými úhly pohledu. Jako jsou různé dokumenty, stejně tak se liší i ony úhly. Mezi písemnostmi jsou dokumenty oficiální, odborné a zejména pak ty další
- dokumenty, které snad ani původně neměly být uchovány. Jako oficiální můžeme jistě označit dokumenty, které se týkají státních pětiletých úkolů. K nim patří plány, průběžné a závěrečné zprávy, zápisy z oponentských řízení, oponentury a další. Najdeme v nich zhuštěné informace o těchto letech, o proběhlých výzkumech a zejména o financích. Pohansko bylo zapojeno do několika státních úkolů - od zahájení výzkumů bylo tvořeno tzv. desítiletí a tzv. 3. pětiletí (do roku 1973). Od roku 1971 se rozběhla 5. pětiletka (1971-1975), na ni navázala 6. pětiletka (1976-1980), 7. pětiletka (1981-1985) a 8. pětiletka (1986-1990).

Dále zde jsou zápisy z jednání Komise pro Pohansko, která vznikla v Břeclavi. Významnou součástí jsou nálezové zprávy, terénní plány, rukopisy četných článků a mnohé další, úzce související s odbornou vědeckou archeologickou prací.

$\mathrm{Na}$ základě dochovaných materiálů si můžeme udělat živoucí představu o organizaci vědecké práce v dobách plánovaného hospodářství a „budování socialismu“. Jak velela tradice doby, úkoly pětiletek byly nejen plněny, ale i překračovány; také problémy s financováním v 80. letech odpovídají své době. Jednotlivé písemnosti jsou jako dílky skládačky, jak přesný ale je složený obraz, těžko posoudit.

Hlavním cílem diplomové práce bylo zjednodušení a zrychlení práce s dokumenty. S již několikaletým odstupem si dovoluji prohlásit, že tohoto cíle bylo dosaženo. Na samotný závěr nezbývá, než vyjádřit naději, že by tento přríspěvek (resp. vlastní diplomová práce) mohl otevřít otázku zpracování archiválií na dalších archeologických lokalitách. Je pochopitelné, že pro archeology - kteří se profesně pohybují ve stovky a tisíce let vzdálené minulosti - se může jevit list, starý 30, 40 let, pouze jako „moderní harampádí“. Nesmíme ale zapomenout, že papír není keramika a bez včasné náležité péče se tyto dokumenty vůbec nedožijí doby, kdy se z nich stane „plnohodnotný historický pramen“. 


\section{Poznámky:}

1) Zvažována byla zejména proto, že část dokumentů týkajících se Pohanska už v AMU je. V tomto př́ípadě se však jedná o dokumenty, do kterých není nutné př́liš často nahlížet.

2) O rozměrech $35 \times 26 \times 11 \mathrm{~cm}$

3) Bohužel ve zprávách je uváděn celkový počet dělníků, včetně těch pracujících na stavbě archeologické základny. V roce 1962 však už dělníci na stavbě nepracovali, a přesto je uváděno 29 dělníků v průměru.

4) Nejedná se o kompletní dějiny archeologických výzkumů na Pohansku u Břeclavi, pouze o těch, které známe z dochovaných písemností. A to zdaleka nemusí být to stejné!

5) Zúčastnili se jej prof. Kalousek, Podborský, Dostál, Verostová, Tejral, Klanica, Spilková, Horňanská, Snášil, Křepelková a Šefčík.

6) Ǩadu zájemců o archeologický výzkum získal prof. Kalousek díky své přednášce o Pohansku v Břeclavi. Hojně navštívená přednáška se konala 23. března 1959 v Grandhotelu Břeclav.

7) Plánovací komise rady ONV v Břeclavi, Odboru výstavby a vodního hosp. rady MNV v Břeclavi, Krajské správy lesů Brno - Lesní závod Podluží, Odboru pro vnitřní věci rady ONV v Břeclavi - okresní inspekce PO, okresního hygienika (Jaroslav Němec) ONV v Břeclavi, Inspektorátu rady ONV v Břeclavi, Krajské vojenské ubytovací a stavební správy Brno a Československých naftových dolů (kvůli napojení elektrické př́pojky na jejich rozvodovou sít).

8) Výzkum žárového pohřebiště podle dochovaných nálezových zpráv probíhal ve dvou etapách. První z nich začala v roce 1961 položením výše zmíněných sond a pokračovala v sezónách 1962-1963. Druhá etapa výzkumu žárového pohřebiště probíhala v letech 1966, 1967 a 1968.

9) Nemovité památky - výšinné opevněné sídliště - hradiště Pohansko [online]. 2003 [cit. 10. prosince 2015]. Dostupné z: http://monumnet.npu.cz/chruzemi/list.php?IdCis=RA\%2C9\&oTypy[0]=RA\&Limit=25

10) Krajské středisko státní památkové péče a ochrany př́rody vyjádřilo svůj souhlas s doporučením „prostor doplnit zelení, aby se objekt lépe začlenil do krajiny.“

11) Popis celé „kauzy trubky“ by byl nad rámec tohoto př́spěvku, stručně jen shrňme, že celá akce se točila kolem 4 trubek z duralové slitiny a táhla se od roku 1966 do roku 1970, aniž by snad přinesla konečné výsledky v podobě fotověže.

12) Stav při dokončování práce na jaře 2012 zůstal nezměněn. Několik urgencí i po odevzdání a obhájení práce zůstalo bez odezvy. Škoda.

13) Na seznamu účastníků sympozia je takřka 90 jmen, řazených v abecedním pořádku, včetně významných archeologů z Moskvy, Berlína, Bukurešti, Varšavy, Poznaně, Kyjeva, Budapešti, Sofie, a pochopitelně také prakticky ze všech významných pracovišt v Československu. Za všechny jmenujme alespoň akademiky Witolda Hensela a Borise Rybakova, prof. Daniila Avdusina, či dr. Marii Comsu.

Pro účastníky byla připravena koženková taška (jedna z nich je součástí dochovaných materiálů na archeologické základně Pohansko), která obsahovala program sympozia (zejména slavnostní zahájení sympozia v pondělí 18. září v 15.00 hod. na ONV Břeclav, další den byla naplánována exkurze na Pohansko (tedy v úterý 19. zárí), dále seznam účastníků a hlavně pak seznam referátů, které byly plánovány na sympoziu zaznít. Součástí „dárkového balení " v tašce byly také brožurky Průvodce archeologickou rezervací Břeclav-Pohansko (vydáno 1963), Chráněná území jižní Moravy, Pavlovské kopce - Československo a Lidová strava na Kloboucku a Ždánicku.

14) Vozidlo bylo odevzdáno zpět dopravnímu oddělení rektorátu UJEP k 31. ř́jnu 1978. Stav tachometru k tomuto datu byl o $3033 \mathrm{~km}$ víc než při převzetí vozu na začátku kalendářního roku.

15) Ministerstvo školství rezervovalo pro fakturaci prací 50000 Kčs, z položky OOV bylo přiděleno dalších 20.000, fakturaci prováděl Český svaz ochránců přírody.

16) Zástupci odboru kultury JmKNV Brno, UJEP Brno, AÚ ČSAV, KSSPPOP Brno, OV KSČ Břeclav a ONV Břeclav.

17) Podle dochovaných písemností bylo na výzkum přiděleno fakultou 20000 Kčs, dodatečně HS přihlásilo na OOV částku 50000 Kčs. Nábor pracovních sil proto nemohl být včas proveden, navíc koncem července bylo z HS přijato sdělení, že přislíbená částka se snížila na 30000 Kčs. V důsledku tohoto se právě prováděný nábor zastavil. Nicméně k 1. ř́ínu 1984 přišlo z HS oznámení, že na OOV pro výzkum na Pohansku u Břeclavi je uvolněná původní přidělená částka 50 000. K tomu dni (1. ř́ijna 1984) bylo vyčerpáno řádných 50000 Kčs (20 000 z fakultního fondu a 30000 z fondu HS), z přesahující částky 20000 byly zaplaceny dokončovací práce a analýza uhlíků a část financí bylo dáno k dispozici fakultě (na výzkum v Těšeticích). 
18) Částka odpovídá mzdě 20 studentů na dobu 2,5 měsíce při odměně 8 ,- až 10,- Kčs za 1 hodinu činnosti.

19) Tato změna byla citelná zejména při platbě zemědělské daně, která se měla zvýšit z dosavadních 176,- Kčs na 685,- Kčs ročně. Katedra archeologie v několika dopisech upozornila na fakt, že areál zabírá pouze nepatrnou část louky a navíc není oplocený, nic tedy nebrání, aby zbytek parcely byl běžně obhospodařován JZD Lanžhot jako sousední parcely. Proto také požádali o přiměřené snížení daně.

20) Skrývka plochy určené pro výzkum byla provedena buldozerem v první polovině května 1986. Bylo za ni vyfakturováno 3500 Kčs + 16002 Kčs, buldozer zajistil Z. Nešpor u Vodohospodářských staveb z Malacek.

21) Z položky OOV bylo na kopáčské práce vynaloženo 36850 Kčs, z položky pracovních smluv na dobu určitou dalších 27600 Kčs; z této částky byla uhrazena i restaurace a inventarizace nálezů (p. Michalica).

22) Cena polského přístroje se podle písemné žádosti o zakoupení př́ístroje pohybovala mezi 15 a 20 tisíci Kčs - od výrobce jej však bylo možné koupit pouze za směnitelné rubly, které byly přidělovány Službou výzkumu v Praze. Bylo zjištěno, že Moravské muzeum disponuje potřebnou částkou směnitelných rublů, a nenajde pro ně v tom roce uplatnění. MZM bylo ochotné přístroj zakoupit a pak za Kčs prodat UJEP.

23) Pro vstup do pohraničního pásma museli brigádníci získat propustku, jejímuž vydání předcházelo několikaměsíční prověřování kádrových faktů. Tento proces značně prodlužoval a komplikoval získávání brigádníků, neumožňoval také pružně reagovat v př́ípadě získání dalších finančních prostředků v průběhu sezóny.

24) Takto např. víme, že V pásmu „Hovoří Morava“ v cyklu „Za objevy moravských archeologů“ odvysílal dne 22. listopadu 1959 v 16:20 brněnský rozhlas 20 minutovou reportáž o Pohansku, jež s redaktorkou Annou Tučkovou připravil prof. František Kalousek. Štastnou náhodou se podařilo v AMU objevit písemný záznam rozhlasové relace, kterou připravila redaktorka Jarmila Lakosilová. Zhruba půlhodinová relace byla vysílána 31. srpna 1965.

\section{Seznam použitých zkratek}

AMU Archiv Masarykovy univerzity

AÚ Archeologický ústav

bm běžný metr

ČSAV Československá akademie věd

FAMU Filmová a televizní fak. akademie múzických umění v Praze

FF Filozofická fakulta

HS Hospodářská správa

JZD Jednotné zemědělské družstvo

KNV Krajský národní výbor

KSČ Komunistická strana Československa

KSSPPOP Krajské středisko Státní památkové péče a ochrany přírody

KV krajský výbor (např. SSM)

LAS Letní aktivita studentů
MM/ MZM Moravské muzeum/ Moravské zemské muzeum v Brně

MNV/ MěNV městský národní výbor

MŠ Ministerstvo školství

MU Masarykova univerzita

ONV okresní národní výbor

OOV ostatní osobní výdaje

OV okresní výbor (např. KSČ)

PS Pohraniční stráž

SE samostatná etapa

SPŠCH Střední průmyslová škola chemická

SPZV státní plán základního výzkumu

SSM Socialistický svaz mládeže

ÚAM Ústav archeologie a muzeologie

UJEP Univerzita Jana Evangelisty Purkyně (název Masarykovy univerzity v letech 1960-1990)

VŠE Vysoká škola ekonomická 


\section{Prameny a literatura}

Archivní fond Břeclav-Pohansko

Inv. č. BP 001 - BP 817

Archiv Masarykovy univerzity

Fond A1 - Rektorát Masarykovy university, sign. CI/3, k. 49

Fond A2 - Filozofická fakulta, katedra archeologie, k. 2

Fond A2 - Filozofická fakulta, katedra archeologie, k. 3

Fond A2 - Filozofická fakulta, katedra archeologie, sig. CI/2, k. 2

\section{Resume}

Within completion of studies of the author in the Department of Auxiliary Historical Sciences and Archive Studies, the written documents accumulated in the archaeological research base at Pohansko were sorted, organized and partly discarded. The diploma thesis was defended in 2012. A total of 817 inventory numbers were assigned, and a collection sized 14,5 bm was established. From the written documents preserved then information was extracted concerning the archaeological excavations from 1958 to 1990.

Materials concerning the so-called five-year plans represent one of the main sources of information on archaeological excavations at the Pohansko u Břeclavi site. Among them are plans, preliminary and final reports, protocols from opposition procedures, external examinations, etc. We find here condensed information on these years, on the excavations performed and mainly on finances. Pohansko was involved in several state tasks - from the beginning of excavations a so-called decennium and a so-called 3rd quinquennium (until 1973) were created. In 1971 started the 5th five-year plan (1971-1975) followed
Dostál, Bořivoj - Vignatiová, Jana (eds.) 1980: Slované 6.-10. století: sborník referátů ze sympozia, Břeclav-Pohansko, 1978. Univerzita J. E. Purkyně, Brno.

Př́loha č. 2 k vyhlášce č. 645/2004 Sb.

Nemovité památky - výšinné opevněné sídliště hradiště Pohansko [online]. 2003 [cit. 10. prosince 2015]. Dostupné z: http://monumnet. npu.cz/chruzemi/list.php?IdCis=RA\%2C9\&oTypy[0] $=$ RA\&Limit $=25$

Salvetová M. 2012: Archeologický výzkum Břeclav-Pohansko ve světle archivních materiálů. Brno: Masarykova univerzita. Nepubl. dipl. práce.

by the 6th five-year plan (1976-1980), 7th five-year plan (1981-1985) and 8th five-year plan (1986-1990) (see Tab. 1).

Trial trenching in the extensive Pohansko stronghold was carried out in 1958, systematic excavations began on 6 May 1959 (the first work team is on Fig. 1). In the next year a brick building was built - the archaeological research base. A decree by the Ministry of Education and Culture from 30 November 1965 has declared the "Břeclav-Pohansko" archaeological reserve (see note 9). Since 1972, the excavation workers have been accommodated in wooden cabins. In the mid-1970s a reconstruction of the archaeological research base was planned but it did not take place due to lack of financial means. Archaeological rescue excavation of the SW suburb began in 1975. In 1978 (20th anniversary of excavations) the international symposium "The 6 th -10 th century Slavs" has taken place. In the 1980s, the excavation suffered from financial insufficiency; in 1983 it was included in "Summer Student Activities".

Among the materials we also find evidence of presentation of archaeological excavations (press, radio, television, exhibitions, lectures). 


\section{Marie Salvetová}

- Ústav archeologie a muzeologie, Filozofická fakulta, Masarykova univerzita, Arna Nováka 1, 60200 Brno 216388@mail.muni.cz 